\title{
PENERAPAN PEMBELAJARAN KOOPERATIF TPS DENGAN PENDEKATAN OPEN ENDED UNTUK MENINGKATKAN KEMAMPUAN BERPIKIR KREATIF MATEMATIS
}

\author{
Krisdiawati \\ Universitas PGRI Ronggolawe J1. Manunggal No.61, Wire, Gedongombo, Tuban 62381, Indonesia \\ kdiawati@gmail.com
}

\begin{abstract}
Abstrak
Tujuan yang ingin dicapai dalam penelitian ini adalah 1) untuk mendeskripsikan kemampuan berpikir kreatif matematis siswa SMP setelah diterapkan pembelajaran TPS dengan pendekatan open ended pada pokok bahasan segiempat, 2) untuk mendeskripsikan respon siswa SMP setelah diterapkannya pembelajaran TPS dengan pendekatan Open-Ended pada pokok bahasan segiempat di SMP. Penelitian ini termasuk penelitian tindakan kelas. Lokasi penelitian di SMP N 2 Widang dengan subjek siswa kelas VII-E sebanyak 25 siswa. Instrumen dalam penelitian ini adalah tes kemampuan berpikir kreatif siswa dan lembar angket respon siswa. Hasil penelitian tes berpikir kreatif diperoleh setelah diterapakannya model think pair share dengan pendekatan open ended menunjukkan bahwa kemampuan berpikir kreatif matematis siswa mengalami peningkatan pada setiap indikatornya, rata-rata kemampuan berpikir kreatif setiap siklus mengalami peningkatan, karena dari rata rata awal 0,3 pada siklus I, mengalami peningkatan menjadi 12,4 pada siklus II, dan pada siklus III juga mengalami peningkatan yakni sebesar 16, dan respon siswa terhadap penggunaan model pembelajaran Think Pair Share dengan pendekatan Open ended terbukti cukup efektif, efisien, dan siswa merespon positif ketika proses pembelajaran berlangsung. Hal ini ditunjukkan dengan hasil penelitian rata-rata presentase respon positif sebesar $99 \%$ dan respon negative sebesar $1 \%$.
\end{abstract}

Kata Kunci: Kemampuan Berpikir Kreatif, Open Ended, TPS

\begin{abstract}
The objectives to be achieved in this study are 1) to describe the mathematical creative thinking ability of junior high school students after TPS learning is implemented with an open-ended approach on the subject matter of quadrilateral, 2) to describe the response of junior high school students after the implementation of TPS learning with the Open-Ended approach on the subject quadrilateral in middle school. This research includes classroom action research. The research location was in SMP N 2 Widang with 25 students of VII-E class students. The instruments in this study were tests of students' creative thinking skills and student response questionnaire sheets. The results of the study of creative thinking tests were obtained after the application of the think pair share model with the open-ended approach showed that students' mathematical creative thinking ability experienced an increase in each indicator, the average creative thinking ability each cycle increased, because from the initial average of 0.3 in the cycle I, increased to 12.4 in the second cycle, and in the third cycle also experienced an increase of 16, and student responses to the use of the Think Pair Share learning model with the Open ended approach proved to be quite effective, efficient, and students responded positively when the learning process take place. This is indicated by the results of the study of the average percentage of positive responses of $99 \%$ and negative responses of $1 \%$.
\end{abstract}

Keywords: Kemampuan Berpikir Kreatif, Open Ended, TPS

\section{PENDAHULUAN}

Untuk menghasilkan generasi yang berkualitas tentunya tidak terlepas dari mutu pendidikan yang diberikan. Seperti yang telah kita ketahui mutu pendidikan di Indonesia ini masih rendah. Hal ini ditunjukkan dengan hasil studi PISA (Program for International Student Assesment) tahun 2015 yang menunjukkan indonesia baru bisa menduduki peringkat 69 dari 76 negara. 
Salah satu cara untuk meningkatkan mutu pendidikan adalah merubah proses pembelajaran. Pembelajaran yang efektif dapat membantu peserta didik untuk meningkatkan kemampuan sesuai kompetensi dasar yang harus dicapai. pembelajaran yang efektif akan terlaksana jika guru dapat memilih pendekatan, strategi dan model pembelajaran yang tepat sehingga tercapai hasil yang semaksimal mungkin.

Matematika sebagai suatu ilmu yang memberikan manfaat diberbagai bidang. Matematika juga membantu dalam perkembangan ilmu pengetahuan lain. Pembelajaran matematika merupakan bagian dari pendidikan. Jadi pembelajaran matematika merupakan salah satu aspek kehidupan yang sangat penting peranannya dalam membentuk generasi yang berkualitas tinggi. Selain itu, karena pelajaran matematika di dalamnya termuat sarana berfikir yang jelas, kritis, kreatif, logis dan sebagai arena untuk memecahkan masalah dalam kehidupan sehari-hari.

Pentingnya pola berpikir kreatif pada matematika juga terdapat pada Kurikulum 2013. Hal ini terbukti dengan adanya Peraturan Pemerintah Nomor 17 Tahun 2010 dalam Kurikulum 2013 tentang Pengelolaan dan Penyelenggaraan Pendidikan, yang menyebutkan bahwa tujuan penyelenggaraan pendidikan dasar dan menengah yaitu membangun landasan bagi berkembangnya potensi siswa agar menjadi manusia yang berilmu, cakap, kreatif, dan inovatif. Kurikulum tersebut juga menyebutkan bahwa salah satu kriteria mengenai kualifikasi kemampuan lulusan yang harus dimiliki oleh siswa yaitu memiliki kemampuan berpikir kreatif dalam ranah abstrak dan konkret sesuai dengan yang dipelajari di sekolah dan sumber lain yang sejenis. Pada matematika, kemampuan berpikir kreatif merupakan produk dari kreativitas matematika sedangkan aktivitas kreatif merupakan kegiatan dalam pembelajaran yang diarahkan untuk mendorong atau memunculkan kreativitas siswa. Walaupun dalam Kurikulum KTSP 2006 maupun Kurikulum 2013, kemampuan berpikir kreatif matematis merupakan kemampuan yang harus dikuasai siswa, akan tetapi pada kenyataannya pengembangan kemampuan tersebut belum optimal.

Hal ini diperkuat berdasarkan hasil observasi di kelas VII E SMP Negeri 2 Widang-Tuban tahun 2017/2018 dapat diketahui bahwa siswa tidak dapat memberikan ide atau cara selain yang terdapat di dalam buku. Hal ini dikarenakan dalam pembelajaran sekarang ini dirasa guru hanya memberikan soal yang bersifat konvergen dimana hanya terdapat satu jawaban yang benar. Dan masalah masalah matematika yang disampaikan guru masih dominan masalah tertutup dengan jawaban tunggal. Masalah terbuka dengan jawaban yang tidak tunggal belum banyak dikenal oleh para guru di sekolah. Guru dapat memberikan soal yang bersifat divergen agar siswa dapat menuangkan ide ide dan imajinasi mereka yang tidak hanya terpaku dengan satu jawaban saja. Dari hasil observasi tersebut mengindentifikasikan bahwa kemampuan berfikir kreatif yang dimiliki siswa dalam proses pembelajaran matematika belum maksimal.

Untuk mewujudkan proses pembelajaran yang baik serta dapat meningkatkan kemampuan berpikir kreatif matematis siswa maka salah satu cara yang dapat dilakukan dengan guru memberikan 
soal yang bersifat devergen sehingga dapat meningkatkan kemampuan berfikir kreatif matematis siswa. Model Pembelajaran Kooperatif TPS adalah model pembelajaran yang menggunakan metode diskusi berpasangan yang dilanjutkan dengan diskusi pleno. Dengan model pembelajaran ini siswa dilatih bagaimana mengutarakan pendapat dan siswa juga belajar menghargai pendapat orang lain dengan tetap mengacu pada materi/tujuan pembelajaran. Pembelajaran matematika melalui pendekatan open ended adalah pembelajaran yang menggunakan masalah open ended dan dimulai dengan memberikan masalah terbuka kepada siswa. Kegiatan pembelajaran harus membawa siswa dalam menjawab permasalahan dengan banyak cara dan mungkin juga banyak jawaban yang benar sehingga mengundang potensi intelektual dan pengalaman siswa dalam proses menemukan sesuatu yang baru.

Penelitian tentang penerapan pembelajaran Kooperatif TPS dengan pendekatan Open ended telah banyak dilakukan sebelumnya, diantara lain adalah Sri (2015) yang menyimpulkan bahwa model pembelajaran Think Pair Share berbasis Open ended dapat meningkatkan kreativitas pemecahan masalah siswa, Marini (2016) yang menyimpulkan bahwa pendekatan open ended dengan teknik kreatif treffinger dapat meningkatkan kreativitas dalam memecahkan masalah, dan Fifi (2017) yang menyimpulkan bahwa pendekatan open ended dapat meningkatkan kemampuan berpikir kreatif siswa.

Bersadarkan paparan tersebut, peneliti mencoba menerapkan kombinasi antara model pembelajaran Kooperatif TPS dengan pendekatan Open Ended pada penelitian tindakan kelas dengan judul "Penerapan pembelajaran Kooperatif TPS dengan pendekatan Open Ended untuk meningkatkan kemampuan berfikir kreatif matematis".

\section{METODE PENELITIAN}

\section{Rancangan Penelitian}

Jenis penelitian yang digunakan adalah Penelitian tindakan kelas (Classroom Action Research). Penelitian tindakan kelas yaitu suatu pencermatan atau pengamatan terhadap tindakan dalam kegiatan pembelajaran yang sengaja dimunculkan dan terjadi dalam sebuah kelas (Arifin,2012:142). Karena sesuai salah satu prinsip PTK yaitu adanya kesadaran diri untuk memperbaiki kinerja. Dalam hal ini peneliti bertujuan untuk meningkatkan kemampuan berpikir kreatif siswa yang semula tidak diperhatikan sehingga menghambat kemampuan berpikir kreatif. Rancangan penelitian tindakan kelas terdiri dari perencanaan, pelaksanaan, pengamatan, refleksi dan perbaikan.

Populasi dalam penelitian ini adalah seluruh siswa kelas VII-E SMP Negeri 2 Widang tahun ajaran 2017/2018 yang berjumlah 25 siswa. Pemilihan SMP Negeri 2 Widang atas pertimbangan bahwa sekolah tersebut memiliki kualitas pendidikan yang tinggi, oleh karena itu penulis ingin mengetahui sejauh mana kemampuan berfikir kretif siswa SMP Negeri 2 Widang.

Peneliti memilih kelas VII E karena hasil observasi peneliti sebelum penelitian yaitu kurangnya kemampuan berfikir kreatif matematis sehingga siswa cenderung pasif dan selalu menunggu instruksi dari guru ketika pembelajaran matematika berlangsung. Dalam penerapan ini peneliti meminta 
informasi kepada guru mata pelajaran tentang kemampuan masing masing siswa terhadap pembelajaran matematika.

Teknik - teknik pengumpulan data yang sesuai dengan permasalahan, yaitu:

Tes dalam penelitian ini dibagi menjadi dua bagian, yaitu :

Pretes

Pretes dilakukan sebelum siklus I, siklus II dan siklus III. Pretes diberikan 2 soal uraian yang memenuhi aspek kognitif berpikir kreatif. Soal dalam pretes memiliki beraneka ragam cara pengerjaan sehingga memunculkan satu hasil.

Postes

Postes dilaksanakan tiga kali yaitu pada setiap siklus. Postes berisikan 2 butir soal uraian yang memenuhi aspek kognitif berpikir kreatis. Postes dikerjakan secara individu dan dilakukan dalam satu pertemuan. Postes bertujuan untuk mengetahui tingkat keberhasilan dari pembelajaran yang dilakukan dengan standar kompetensi berpikir kreatif.

Angket Respon Siswa

Angket adalah sejumlah pertanyaan tertulis yang digunakan untuk memperoleh informasi dari responden dalam arti laporan tentang pribadinya atau hal-hal yang diketahui (Arikunto, 2013:194).

Angket digunakan untuk memperoleh data tentang respon siswa adalah angket terbuka sebanyak 8 pertanyaan, angket diberikan kepada siswa setelah mengikuti pembelajaran melalui pembelajaran Kooperatif TPS dengan pendekatan Open ended. Dari jawaban-jawaban yang diberikan siswa ini maka dapat diperoleh gambaran tanggapan atau pendapat tentang pelaksanaan pembelajaran melalui pembelajaran Kooperatif TPS dengan pendekatan Open ended.

Angket diberikan kepada siswa setelah semua siklus selesai dilaksanakan. Jadi, pemberian angket diberikan sebanyak satu kali pada penelitian ini.

Adapun instrumen yang digunakan dalam penelitian ini yaitu:

1. Tes Kemampuan Berpikir Kreatif

Tes adalah serentetan pertanyaan atau latihan serta alat lain yang digunakan untuk mengukur keterampilan, pengetahuan intelegensi, kemampuan atau bakat yang dimiliki oleh individu atau kelompok (Arikunto, 2013:193). Tes ini digunakan oleh peneliti untuk mendapatkan data kuantitatif, nilai tes berpikir kreatis siswa yang berbentuk soal uraian sebanyak 2 butir. Tes yang digunakan adalah tes setiap akhir siklus I, II, dan III yang divalidasi oleh dua guru mata pelajaran matematika berkompeten dan tes kemampuan awal individu atau pretest.

Berikut gambaran penilaian penskoran tes kemampuan berpikir kreatif matematis siswa disajikan pada tabel berikut ini.

\section{Tabel Pedoman Penskoran}

\begin{tabular}{ccccc}
\hline No & Indikator & \multicolumn{1}{c}{ Kriteria } & Kualitas & Skor \\
\hline Kefasihan & $\begin{array}{l}\text { Siswa menunjukkan rencana pemecahan } \\
\text { masalah yang bermacam macam dan semuanya } \\
\text { betul. (lebih dari satu macam) }\end{array}$ & $\begin{array}{l}\text { Sangat } \\
\text { fasih }\end{array}$ & 3 \\
\end{tabular}




\begin{tabular}{|c|c|c|c|c|}
\hline No & Indikator & Kriteria & Kualitas & Skor \\
\hline & & $\begin{array}{l}\text { Siswa menunjukkan satu atau dua macam } \\
\text { rencana pemecahan masalah dan semuanya } \\
\text { betul. Astau siswa menunjukkan lebih dari dua } \\
\text { macam pemecahan masalah, tetapi ada } \\
\text { sebagian rencana yang dituliskan/disebutkan } \\
\text { salah }\end{array}$ & Fasih & 2 \\
\hline & & $\begin{array}{l}\text { Siswa menunjukkan satu atau dua macam } \\
\text { rencana pemecahan masalah, tetapi ada } \\
\text { sebagian yang dituliskan salah. }\end{array}$ & $\begin{array}{l}\text { Kurang } \\
\text { Fasih }\end{array}$ & 1 \\
\hline & & $\begin{array}{l}\text { Siswa tidak menunjukkan rencana pemecahan } \\
\text { masalah dengan atau menunjukkan satu atau } \\
\text { dua pemecahan masalah,tetapi semuanya } \\
\text { bernilai salah. }\end{array}$ & $\begin{array}{l}\text { Tidak } \\
\text { Fasih }\end{array}$ & 0 \\
\hline \multirow[t]{4}{*}{2} & $\begin{array}{l}\text { Fleksibilita } \\
\text { s }\end{array}$ & $\begin{array}{l}\text { Siswa dapat mengubah rencana pemecahan } \\
\text { masalah satu ke pemecahan masalah lain yang } \\
\text { berbeda sebanyak lebih dari dua macam dan } \\
\text { semuanya betul. }\end{array}$ & $\begin{array}{l}\text { Sangat } \\
\text { Fleksibel }\end{array}$ & 3 \\
\hline & & $\begin{array}{l}\text { Siswa dapat mengubah rencaa pemecahan } \\
\text { masalah satu ke pemecahan masalah lain yang } \\
\text { berbeda sebanyak satu atau dua. Atau siswa } \\
\text { dapat mengubah pemecahan masalah satu ke } \\
\text { masalah lain yang berbeda sebanyak lebih dari } \\
\text { dua, tetapi 1ada sebagian jawaban yang } \\
\text { dituliskan salah. }\end{array}$ & Fleksibel & 2 \\
\hline & & $\begin{array}{l}\text { Siswa dapat mengubah rencana pemecahan } \\
\text { masalah satu ke pemecahan masalah lain yang } \\
\text { berbeda sebanyak satu atau dua, tetapi hanya } \\
\text { sebagian masalah yang dapat ditulis. }\end{array}$ & $\begin{array}{l}\text { Kurang } \\
\text { Fleksibel }\end{array}$ & 1 \\
\hline & & $\begin{array}{l}\text { Siswa tidak dapat mengubah rencana } \\
\text { pemecahan masalah satu rencana ke rencana } \\
\text { pemecahan lain yang berbeda atau dapat } \\
\text { mengubah rencana pemecahan masalah satu ke } \\
\text { rencana pemecahan lain yang berbeda,tetapi } \\
\text { bernilai salah }\end{array}$ & $\begin{array}{l}\text { Tidak } \\
\text { Fleksibel }\end{array}$ & 0 \\
\hline \multirow[t]{4}{*}{3.} & Kebaruan & $\begin{array}{l}\text { Siswa menunjukkan rencana pemecahan } \\
\text { masalah yang berbeda beda (sebanyak satu } \\
\text { atau dua) dan menuliskan dengan benar. Atau } \\
\text { menunjukkan satu atau lebih pemecahan } \\
\text { masalah dengan benar. }\end{array}$ & $\begin{array}{l}\text { Sangat } \\
\text { baru }\end{array}$ & 3 \\
\hline & & $\begin{array}{l}\text { Siswa menunjukkan rencana pemecahan } \\
\text { masalah yang berbeda beda (sebanyak satu } \\
\text { atau dua) dan menuliskan dengan benar. Atau } \\
\text { menunjukkan pemecahan masalah yang } \\
\text { berbeda beda (sebanyak lebih dari dua), tetapi } \\
\text { ada sebagian yang dituliskan salah }\end{array}$ & Baru & 2 \\
\hline & & $\begin{array}{l}\text { Siswa menunjukkan rencana pemecahan } \\
\text { masalah yang berbeda beda (sebanyak satu } \\
\text { atau dua), tetapi hanya dapat menuliskan } \\
\text { sebagian yang betul. }\end{array}$ & $\begin{array}{l}\text { Kurang } \\
\text { Baru }\end{array}$ & 1 \\
\hline & & $\begin{array}{l}\text { Siswa menunjukkan rencana pemecahan } \\
\text { masalah yang berbeda beda, atau tidak } \\
\text { menunjukkan satu pengajuan masalah yang } \\
\text { tidak biasa dilakukan oleh individu siswa pada }\end{array}$ & $\begin{array}{l}\text { Tidak } \\
\text { Baru }\end{array}$ & 0 \\
\hline
\end{tabular}




\begin{tabular}{|c|c|c|c|c|}
\hline No & Indikator & Kriteria & Kualitas & Skor \\
\hline & & $\begin{array}{l}\text { tahap perkembangannya atau tingkat } \\
\text { pengetahuannya, atau menunjukkan } \\
\text { pemecahan masalah yang berbeda beda, tetapi } \\
\text { bernilai salah. }\end{array}$ & & \\
\hline
\end{tabular}

Adopsi warli (dalam Retno, 2016)

2. Analisis Data Angket Respon Siswa

3. Data hasil angket respon siswa setelah mengikuti proses pembelajaran matematika menggunakan model pembelajaran Kooperatif TPS dengan pendekatan Open ended dengan mencari persentase jawaban siswa untuk setiap kategori yang dinyatakan dalam angket. Persentase dari tiap respon siswa dihitung dengan menggunakan rumus sebagai berikut.

$$
\operatorname{Pr}=\frac{B}{n} \times 100 \%
$$

Sumber : (Warli dalam Yunitasari, 2017 : 57)

Keterangan:

Pr: Persentase banyak siswa yang memberikan respon positif terhadap katagori yang ditanyakan dalam angket

B: Banyak siswa yang memberikan respon positif terhadap kategori yang ditanyakan dalam angket

n: Banyak siswa yang menjadi responden

$\operatorname{Pr} \geq 75 \%$ respon siswa dikatakan positif bila presentase respon lebih dari atau sama dengan $75 \%$.

\section{HASIL PENELITIAN DAN PEMBAHASAN}

Setelah peneliti melakukan penelitian, peneliti dapat mendiskripsikan hasil penelitian sebagai berikut:

1. Kemampuan berpikir kreatif

Rata-rata kemampuan berpikir kreatif matematis siswa pada siklus I, II dan III ditampilkan pada Tabel 1 berikut:

Tabel 1 Siklus I, II, dan III

\begin{tabular}{|c|c|c|c|}
\hline \multirow{2}{*}{ Siklus } & \multicolumn{3}{|c|}{ Indikator } \\
\cline { 2 - 4 } & Kefasihan & Fleksibilitas & Kebaruan \\
\hline I & 0,3 & 0 & 0 \\
\hline II & 2,3 & 3,7 & 6,2 \\
\hline III & 3 & 4,4 & 8,5 \\
\hline
\end{tabular}

\section{Hasil Angket Respon Siswa}

Hasil analisis respon siswa menunjukkan bahwa respon positif siswa sebanyak $99 \%$ dan respon negatif sebanyak 1\%. Dari data hasil analisis respon siswa didapatkan respon positif lebih banyak dari pada respon negatif. Jadi, dapat disimpulkan bahwa penerapan model pembelajaran 
Kooperatif TPS dengan pendekatan Open ended mendapatkan respon positif dari kelas VII E SMP N 2 Widang.

1. Kemampuan berpikir kreatif

Berdasarkan tabel dapat dijelaskan bahwa kualitas kemampuan berpikir kreatif siswa mengalami peningkatan. Peningkatan tersebut dapat di uraikan sebagai berikut.

a. Indikator kefasihan mengalami peningkatan dari rata rata 0,3 pada siklus I menjadi 2,3 pada siklus II dan meningkat lagi menjadi 3 pada siklus III.

b. Indikator fleksibilitas mengalami peningkatan dari rata rata 0 pada siklus I menjadi 3,7 pada siklus II dan meningkat lagi menjadi 4,4 pada siklus III.

c. Indikator kebaruan mengalami peningkatan dari rata rata 0 pada siklus I menjadi 6,2 pada siklus II dan meningkat lagi menjadi 8,5 pada siklus III.

2. Angket Respon Siswa

Berdasarkan perhitungan angket respon siswa dapat dikatakan bahwa semua pertanyaan yang diberikan kepada siswa mengenai kegiatan pembelajaran yang telah berlangsung selama $3 \mathrm{x}$ pertemuan (3 siklus) menghasilkan respon yang cukup efektif.

Hal ini ditunjukkan dengan hasil penelitian rata-rata presentase respon siswa 99\% karena lebih besar dari $75 \%$ dan yang merespon negatif sebanyak $1 \%$ maka dapat dikatakan respon positif

\section{KESIMPULAN}

Kemampuan berpikir kreatif siswa kelas VII-E SMP N 2 WIDANG, melalui model pembelajaran Kooperatif TPS dengan pendekatan Open Ended pokok bahasan bagun datar mengalami peningkatan. Hal ini, terlihat dari adanya peningkatan nilai rata-rata kemampuan berpikir kreatif pada setiap siklusnya. Kemampuan berpikir kreatif siswa pada siklus I rata-rata total 0,3, siklus II dengan rata-rata total 12,4, dan siklus III rata-rata total 16.

Respon siswa pada pembelajaran matematika melalui model pembelajaran Kooperatif TPS dengan pendekatan Open ended dikelas VII-E SMP N 2 Widang tahun pelajaran 2017/2018 siswa merespon positif. Hal ini, terlihat dari hasil penelitian rata rata presentase respon siswa $99 \%$.

\section{REFERENCES}

Arifin, Zaenal. 2012. Metodologi Penelitian Pendidikan Filosofi, Teori \& Aplikasinya. Surabaya: Lentera Cendekia.

Arikunto, Suharsimi. 2013. Prosedur Penelitian Suatu Pendekatan Praktik. Jakarta: PT Rineka Cipta.

Depdiknas. (2006). Peraturan Menteri Pendidikan Nasional Nomor 22 Tahun 2006 Tentang Standar Isi untuk Satuan Pendidikan Dasar dan Menengah.

Shoimin, Aris 2013. Model Pembelajaran Inofatif dalam Kurikilum 2013. Ar-RuzMedia 
Yunitasari, Nova Rusti. 2017. Penerapan Model Pembelajaran Co-Op Co-Op dengan Setting Cooperative Script Untuk Meningkatkan Kemampuan Komunikasi Matematis Siswa. Skripsi tidak dipublikasikan. Unirow Tuban 